\title{
Potential interaction between proton pump inhibitor and clopidogrel
}

\author{
Indra Kurniawan, ${ }^{1}$ Marcellus Simadibrata ${ }^{2}$ \\ ${ }^{1}$ Bhakti Wara Hospital, Pangkalpinang, Bangka Belitung Archipelago, Indonesia \\ ${ }^{2}$ Department of Internal Medicine, Faculty of Medicine Universitas Indonesia / Dr. Cipto Mangunkusumo Hospital, Jakarta, Indonesia
}

\begin{abstract}
Abstrak
Klopidogrel adalah obat anti-platelet yang banyak digunakan pada penyandang kardiovaskular (CV) aterosklerosis. Walaupun awalnya dianggap aman, sejumlah studi melaporkan bahwa penggunaan klopidogrel menyebabkan peningkatan signifikan kejadian perdarahan gastrointestinal (GI). Kejadian ini dapat diminimalisasi dengan pemberian penghambat pompa proton (PPI). Namun, karena PPI dan klopidogrel mempunyai jalur metabolisme yang sama, dihipotesiskan bahwa pemberian PPI pada terapi klopidogrel menyebabkan terjadinya penurunan efek anti-platelet klopidogrel, yang dapat meningkatkan risiko terjadinya kejadian kardiovaskular. Studi terkini melaporkan bahwa tidak terjadi penghambatan yang bermakna pada aktivasi klopidogrel oleh CYP2C19 dengan pemberian PPI in-vitro. Sejumlah studi farmakokinetik, farmakodinamik, serta studi klinis melaporkan hasil yang masih bertentangan menyangkut kemungkinan interaksi antara PPI dan klopidogrel. Hingga kini, sebagian besar studi yang ada untuk menyelidiki interaksi PPI-klopidogrel bersifat observasional. Studi COGENT merupakan satu-satunya studi prospektif, plasebo-terkontrol yang memeriksa interaksi PPIklopidogrel. Studi ini menunjukkan bahwa tidak ada peningkatan kejadian kardiovaskular secara bermakna pada pasien yang mendapatkan PPI dan klopidogrel, dibandingkan dengan kelompok kontrol. Walaupun masih bersifat kontroversial, konsensus ahli terkini merekomendasikan pemberian PPI pada pasien yang mendapatkan klopidogrel, khususnya pasien dengan risiko tinggi. (Med J Indones. 2013;22:57-62)
\end{abstract}

\begin{abstract}
Clopidogrel is an anti-platelet agent commonly used in patients with atherosclerotic cardiovascular (CV) disease. Although formerly considered safe, several studies reported that the use of clopidogrel may cause a significant increase in the rate of gastrointestinal (GI) bleeding. This adverse effect could be minimized by coadministration of proton pump inhibitor (PPI). However, since PPI and clopidogrel share the same metabolic pathway, it has been hypothesized that the administration of PPI following clopidogrel therapy may cause a reduction in its anti-platelet effect, thereby increasing the risk of CV events. Recent studies found no significant inhibition in the activation of clopidogrel by CYP2C19 with administration of PPI in vitro. Pharmacokinetic and pharmacodynamic studies, as well as clinical studies, reported conflicting results regarding the potential interaction between PPI and clopidogrel. Until now, the available study investigated the PPI-clopidogrel interaction are primarily observational. The COGENT study is the only prospective, placebo-controlled trial examined the PPI-clopidogrel interaction. This study revealed no significant increase in CV events in patients receiving PPI following clopidogrel therapy, compared to the control group. Though remains controversial, current expert consensus recommended the administration of PPI in patients receiving clopidogrel, particularly in highrisk patients. (Med J Indones. 2013;22:57-62)
\end{abstract}

Keywords: Cardiovascular, clopidogrel, gastrointestinal, proton pump inhibitor

Clopidogrel is an anti-platelet agent widely used in patients with atherosclerotic cardiac or cerebrovascular disease. In some patients, to increase its effectiveness, this agent can be given in combination with aspirin. Although formerly considered safe, several studies reported that the use of clopidogrel may cause an increase in the incidence of gastrointestinal (GI) bleeding. Thus, current consensus recommended prescribing a Proton Pump Inhibitor (PPI) in high risk patients receiving clopidogrel, alone or in combination with aspirin. ${ }^{1-3}$

However, the use of a PPI in addition to clopidogrel therapy, have raised concerns about the potential interaction between these agents since these drugs shared a common metabolic pathway. Clopidogrel is a prodrug that requires cytochrome P 450 (CYP) enzymes to be converted to its active metabolite. On the other hand, PPI also requires CYP enzymes to be converted from their active to their inactive state. Thus, it has been postulated that PPI may reduce the effectiveness of clopidogrel by competitively inhibiting CYP enzymes which play an important role in the activation of clopidogrel. ${ }^{1-4}$

\section{Risk of GI bleeding in clopidogrel therapy}

It has been known that anti-platelet therapy may cause an increase in the incidence of GI bleeding which can occurred in various lesions and anatomic sites. Recent studies reported that there are several risk factors which may predispose patients to develop GI bleeding. The strongest risk factor is a history of bleeding or complications of peptic ulcer disease. Since the incidence of GI bleeding is higher in the elderly people, advancing age is also considered as a risk factor of upper GI bleeding. Other risk factors should also be sought including chronic use of anticoagulants, NSAIDs, or steroids, as well as $H$. pylori infection. The relative risk of GI bleeding is significantly associated with the number of risk factors present in a patient. ${ }^{1,4-7}$ 
Clopidogrel-associated GI bleeding is strongly associated with its potent anti-platelet activity. As an anti-platelet, clopidogrel may inhibit the release of pro-angiogenic growth factors from the platelet, which play an important role in promoting the healing of gastroduodenal lesions that developed due to other causes, such as $H$. pylori infection, and chronic use of NSAIDs or steroids. As a result, significant ulcerations and complications can be occurred, particularly in the presence of uncontrolled acid. However, further randomized, placebo-controlled trials are required to confirm the pathogenesis of clopidogrel-associated GI bleeding. ${ }^{1,5,6,8,9}$

CAPRIE (Clopidogrel versus Aspirin in Patients at Risk of Ischemic Events) study compared the efficacy of clopidogrel $75 \mathrm{mg}$ daily with asetil-salycilic acid (ASA) $325 \mathrm{mg}$ daily (high cardioprotective dose) in preventing the vascular ischemic events in patients without multiple risk factors for GI bleeding. The incidence rate of severe GI bleeding in the clopidogrel group $(0.52 \%)$ is lower than in the ASA group $(0.72 \%$, p $<0.05)$. However, it should be noted that the difference in the incidence rate of severe GI bleeding with the use of these agents was relatively small $(0.2 \%)$. Thus, further studies are required to confirm the safety of clopidogrel to the GI system. ${ }^{1,5,8,9}$

Several studies have investigated the safety of clopidogrel to the GI system in patients with multiple risk factors for GI bleeding. In a retrospective study, 9 from 70 patients (12\%) developed GI bleeding following ingestion of clopidogrel for one year. On endoscopic examination, it was found that almost all GI bleeding came from the previous lesions, suggesting that altered hemostasis following clopidogrel therapy may precipitate bleeding from previous ulcers. ${ }^{8}$

A prospective, double-blind, randomized controlled trial compared the incidence of GI bleeding between clopidogrel $75 \mathrm{mg}$ daily and ASA $80 \mathrm{mg}$ daily plus esomeprazole $20 \mathrm{mg}$ twice daily in $320 \mathrm{H}$. pylorinegative patients for 12 months. The incidence rate of GI bleeding was significantly higher in the clopidogrel group (8.6\%), as compared to the ASA plus esomeprazole griup $(0.07 \%, \mathrm{p}=0.001)$. Among the GI bleeding in the clopidogrel group, $71 \%$ source of bleeding came from the previous lesions. ${ }^{5-9}$

Another randomized controlled trial with similar design also compared the same outcome, except of using lower dose of esomeprazole ( $20 \mathrm{mg}$ daily). After a follow up of one year, the incidence rate of GI bleeding was significantly higher in the clopidogrel group (13.6\%), as compared to the ASA plus esomeprazole group $(0 \%$, $\mathrm{p}=0.001)^{8,9}$
From these studies, it could be concluded that clopidogrel therapy alone is not safe for patients with multiple risk factors for GI bleeding, and coadministration of PPI should be taken into consideration for these patients. Although most of GI bleeding came from the previous lesions, further studies are needed to confirm the possibility that clopidogrel may induce GI bleeding through its anti platelet effects. ${ }^{6-9}$

Furthermore, several studies have suggested that the incidence of clopidogrel-associated GI bleeding may be reduced by coadministration with PPI, since PPI can suppress gastric acid production, thereby promoting the healing of gastroduodenal lesions. Hence, current expert recommendations stated that PPI should be given following clopidogrel therapy in patients with multiple risk factors for GI bleeding. ${ }^{4,6,8-10}$

\section{The role of PPI in clopidogrel-associated GI bleeding}

A large case-control study compared the incidence of GI bleeding between clopidogrel therapy alone with clopidogrel-PPI cotherapy in 2779 patients with endoscopically confirmed upper GI bleeding and 5532 controls. The relative risk of GI bleeding was lower in the clopidogrel-PPI cotherapy group than clopidogrel therapy alone (RR: $0.19,95 \%$ CI $0.07-0.49$ ). This finding suggests that PPI cotherapy may play a role in reducing the risk of GI bleeding. ${ }^{1,11}$

Preliminary analysis of a randomized, double blind trial investigated the GI events, such as overt or occult GI bleeding, symptomatic gastroduodenal lesions, in patients taking PPI (omeprazole) vs placebo following ingestion of dual anti-platelet therapy (clopidogrel plus ASA). The patients with PPI cotherapy reported fewer GI events, as compared to the placebo group (HR: 0.55, 95\% CI: 0.36-0.85). This study suggested that PPI therapy should be considered in patients receiving dual anti-platelet therapy to minimize GI events. However, the study was terminated before the pre-specified sample size and duration were reached. Further studies are needed to confirm the beneficial effect of PPI in reducing GI events in patients receiving clopidogrel. ${ }^{1,3,8}$

\section{Hypotheses regarding the potential interaction between PPI and clopidogrel}

\section{Reduction in the biological action of clopidogrel through competitive metabolic effects of CYP2C19}

To be clinically effective, clopidogrel needs to be converted from a prodrug to its active metabolite by the cytochrome P450 (CYP450) system. On the other hand, PPI are also metabolized by the CYP450 
system. It has been postulated that coadministration of PPI following clopidogrel therapy may competitively inhibit the activation of clopidogrel by CYP2C19, thereby attenuating its clinical efficacy in inhibiting platelet aggregation. This potential interaction should be evaluated carefully since current expert consensus recommended the use of PPI following clopidogrel therapy for gastroprotection, particularly if clopidogrel is given in combination with aspirin. ${ }^{4,10-13}$

\section{Reduction in the biological action of clopidogrel related to genetic polymorphisms}

Recent studies reported that there is a natural variation in CYP2C19 activity among population, based on genetic polymorphisms. The CYP2C19 polymorphism may cause a reduction in the anti-platelet activity of clopidogrel, thereby increasing rate of cardiovascular (CV) events, including CV death, myocardial infarction, stroke, as well as stent thrombosis. The most common loss-of-function polymorphism is the CYP2C19*2 allele, which is carried by $\pm 50 \%$ of Asians. Several studies have suggested that higher clopidogrel doses can be given to overcome this problem. However, it should be noted that higher dose treatment to achieve an adequate $\mathrm{CV}$ efficacy must be weighed against an increased risk of GI bleeding. ${ }^{11,14-16}$

\section{The pharmacokinetic and pharmacodynamic effect of clopidogrel following the administration of PPI}

Recent expert consensus recommended the administration of PPI following clopidogrel therapy to minimize the chances of GI bleeding, particularly in patients with multiple risk factors. Since metabolism of both PPI and clopidogrel involves CYP2C19, it has been postulated that PPI cotherapy may competitively inhibit the activation of clopidogrel, thereby reducing its anti-platelet effect and increasing CV events. There are conflicting results regarding the potential interaction between PPI and clopidogrel. Several studies reported a decreased anti-platelet effect of clopidogrel following coadministration of PPI. On the other hand, other studies showed no significant reduction in the antiplatelet effect of clopidogrel in PPI cotherapy. ${ }^{10,12,13}$

Gilard et al. compared anti platelet effect between patients taking clopidogrel plus PPI and those taking clopidogrel without PPI using a novel surrogate marker for CV events, which is called platelet reactivity index (PRI). They reported that a higher PRI index $(61.4 \%)$ in patients taking clopidogrel plus PPI than those without PPI $(49.5 \%, \mathrm{p}=$ 0.007). A randomized, double-blind, placebo-controlled trial with similar design found a significant increase in the number of poor responders (PRI $>50 \%$ ), in patients taking clopidogrel plus omeprazole $(60.9 \%)$ than those without omeprazole $(26.7 \%, \mathrm{p}<0.001){ }^{1,12,13}$

The finding in these studies indicated that there might be a reduced anti-platelet effect of clopidogrel following the administration of PPI. It has been postulated that competitive inhibition of CYP2C19 between PPI and clopidogrel might play a role in this situation. However, recent studies found no significant inhibition in the activation of clopidogrel by CYP2C19 with administration of PPI in vitro. ${ }^{12,13}$

A randomized, open-label crossover study reported that ADP-induced platelet aggregation was not significantly different in patients taking clopidorel plus lansoprazole than those without lansoprazole. A cohort study compared the PRI and ADP-induced platelet aggregation between patients taking clopidogrel plus PPI and those without PPI. After a follow up of 3 months, the PRI and ADP-induced platelet aggregation were not significantly different between the study groups. ${ }^{1}$

Post hoc analysis from a randomized controlled trial compared ADP-induced platelet aggregation in patients undergoing percutaneous coronary intervention taking clopidogrel plus PPI and those taking clopidogrel without PPI. The study reported a significant decrease in platelet inhibition in patients taking clopidogrel plus PPI than those without PPI. However, it should be noted that the result of this post hoc analysis should be validated with data from randomized clinical trials. ${ }^{1,4}$

\section{The influence of PPI on clinical outcomes with clopidogrel therapy}

Several observational studies compared the risk of $\mathrm{CV}$ events between patients taking clopidogrel plus PPI and those taking clopidogrel alone. There are conflicting results among these studies, since some studies reported a small but significant increase in $\mathrm{CV}$ events in patients taking clopidogrel plus PPI, while other studies reported no association between $\mathrm{CV}$ events and the use of PPI. $2,3,10,11,17$

In studies that reported an increase of $\mathrm{CV}$ events, the magnitude of the treatment effect has been modest (risk ratios 1.25-2.00). Thus, it has been suggested that the finding in these observational studies could be caused by differences in confounding variables, between the patients who received PPI following clopidogrel therapy and those without PPI, such as genetics (rapid or poor CYP2C19 metabolizers), medications (aspirin, beta blockers, calcium channel blickers, statins), as well as other medical disorders (heart failure, diabetes, 
hyperlipidemia). However, there are no retrospective studies which have been adequately matched for excluding these confounding variables. ${ }^{2,5,10,17}$

A non-randomized subgroup analysis within a randomized trial examined whether the administration of PPI may influence the clinical efficacy of clopidogrel or prasugrel in reducing $\mathrm{CV}$ events in 13608 patients. This study showed that the use of PPI did not influence the $\mathrm{CV}$ outcomes, either among patients taking clopidogrel (HR: $0.94 .95 \%$ CI: $0.80-1.11$ ), or among patients taking prasugrel (HR:1.00. 95\% CI: 0.841.20). This study also showed that there is no increased risk of $\mathrm{CV}$ events in patients prescribed different classes of PPIs, including omeprazole, lansoprazole, esomeprazole, and pantoprazole. The result of this study was similar among those who is classified as poor metabolizer of CYP2C19.,11

In the CREDO (Clopidogrel for Reduction of Events During Observation) study, it was shown that the use of PPI is associated with an increased rate of CV events. However, this finding was also occurred among patients taking placebo plus PPI. The result of this study suggested that sicker patients or patients with higher risk of $\mathrm{CV}$ events were the ones most likely to receive PPIs. Therefore, the presence of confounding variables should be considered in assessing the results of these observational studies, since the major concern in observational studies is the difficulty to exclude unmeasured confounders. ${ }^{1,4,11,18}$

The COGENT (The Clopidogrel and the Optimization of Gastrointestinal Events) study was the only doubleblind, placebo-controlled trial investigated the interaction of PPI and clopidogrel in CV and GI events. In this study, 3761 patients with acute coronary syndromes or undergoing PCI were randomized to received dual anti-platelet therapy (clopidogrel and aspirin) plus omeprazole or without omeprazole. Although this study was stopped early, the data from this study showed no significant difference in $\mathrm{CV}$ outcomes between patients taking dual anti-platelet therapy plus PPI and those without PPI (HR: 0.99 95\% CI: 0.68-1.44). ${ }^{3}$

On the other hand, the conflicting result from these studies may also be caused by varying distribution of CYP2C19 genotypes among the populations studied that may confer different susceptibilities to the interaction between PPI and clopidogrel. As mentioned before, clopidogrel is a prodrug that requires several enzymes, particularly CYP2C19, to be converted to its active metabolite. Recent studies found that patients with reduced-funtion of CYP2C19 (also called as poor metabolizers for CYP2C19) may have decreased activation and anti-platelet effect of clopidogrel, resulting in increased rate of $\mathrm{CV}$ events among patients taking clopidogrel. However, a multivariate analysis in one of these studies showed that the increased risk of $\mathrm{CV}$ events-associated with CYP2C19 reduced-function was not influenced by the administration of PPIs. ${ }^{14-17}$

\section{Different effect of different PPIs}

Pharmacokinetic studies reported that all PPIs reduce the activity of CYP12C19 enzymes to varying degrees in vitro. Pharmacodynamic studies, using PRI and ADPinduced platelet aggregation as surrogate markers for CV events, revealed an inhibitory effect of CYP2C19 activity by different PPIs to varying degrees. However, there is only a few studies investigated the different effect of different PPIs in patients receiving clopidogrel. ${ }^{11}$

One observational study reported that there is no increased risk of $\mathrm{CV}$ events on the use of pantoprazole following clopidogrel therapy. In the contrary, the use of other PPIs is associated with an increased risk of $\mathrm{CV}$ events. However, there is no significant difference in the risk of $\mathrm{CV}$ events between patients received pantoprazole and those received other PPIs. It has been postulated that this difference may be due to pantoprazole's lesser CYP2C19 inhibition, when compared to other PPIs. ${ }^{11}$

A non-randomized subgroup analysis within a randomized trial examined showed that there is no increased risk of $\mathrm{CV}$ events in patients prescribed different classes of PPIs, including omeprazole, lansoprazole, esomeprazole, and pantoprazole. Two other observational studies reported that the increased risk of $\mathrm{CV}$ events of patients prescribed rabeprazole, esomeprazole, and pantoprazole is the same as those prescribed omeprazole or lansoprazole, whereas other observational studies showed that there is no increased risk of CV events for all PPIs. ${ }^{11}$

From these studies it could be seen that although pharmacokinetic and pharmacodymamic studies showed an inhibition of CYP2C19 enzymes by PPIs to varying degrees, there is no strong evidence which proved that the differences on surrogate markers indicated a significant difference in clinical outcomes. Further prospective trials are needed to learn more about the clinical efficacy of clopidogrel on the use of different PPIs. ${ }^{11}$

\section{Timing of dosing to minimize the interaction between PPI and clopidogrel}

Since both PPI and clopidogrel are given once daily and their plasma half-lives are short, it has been suggested 
that separation the timing of drug administration is beneficial in minimizing the potential interaction between PPI and clopidogrel. A recent study showed that this strategy can also be applied to the patients who are classified as poor CYP2C19 metabolizers. ${ }^{1,2,10,11,18}$

A crossover study investigated the inhibition of platelet aggregation in 72 healthy subjects receiving standarddose of clopidogrel (300 mg at the first day, followed by $75 \mathrm{mg}$ daily) and a high-dose of omeprazole ( 80 mg daily). This study reported that the optimal platelet inhibition was achieved when the drugs were given 12 hours apart. However, further studies are required to confirm this hypothesis. Since there is only a few data regarding this issue, the current evidence could not conclude any recommendation. ${ }^{10,11}$

\section{Recommendations from the studies}

Until now, the available study investigated the potential interaction between PPI and clopidogrel in CV events are primarily observational. In observational studies, the exposures that received by the subjects are determined by the subject characteristics and/ or clinical decisions of health-care providers, instead of randomization. Therefore, there might be a higher number of confounding factors which may alter the result of the study. As a result, a valid statistical association is not easy to be concluded, when the effect sizes of observational studies are small to moderate $(\mathrm{RR}<1.25-2.00)$. Thus, randomized trials with sufficient sample size and duration of study, which may adequately control for confounding results, are needed to conclude a valid statistical association..$^{1,10,17}$

Several studies concluded that the use of PPI might decrease the anti-platelet effect and clinical efficacy of clopidogrel, based on positive results in some of the observational studies and hypotheses regarding the potential interaction between PPI and clopidogrel. The COGENT study was the only double-blind, randomized trial available in investigating the interaction of PPI and clopidogrel in $\mathrm{CV}$ events. This study revealed no significant difference in $\mathrm{CV}$ events between patients taking clopidogrel plus PPI and those without PPI. The current evidence does not conclude that PPI are associated with higher $\mathrm{CV}$ events in patients receiving clopidogrel. ${ }^{1,3,17}$

Furthermore, current clinical evidence does not show that one PPI is different from the others in the interaction with clopidogrel, so merely switching from one PPI to the others to minimize the PPI-clopidogrel interaction is not recommended. Randomized clinical trials are required to investigate whether switching from one PPI to the others or changing to a histamin $\mathrm{H} 2$-receptor antagonist is beneficial in reducing the possibility of PPI-clopidogrel interaction. ${ }^{1,11}$

On the other hand, several studies reported that the use of clopidogrel alone, without PPI, is associated with higher rates of GI bleeding. Therefore, it has been suggested that the administration of PPI as GIprotective therapy should be considered in patients receiving clopidogrel therapy, particularly in highrisk patients such as those with multiple risk factors for GI bleeding or receiving dual anti-platelet therapy (clopidogrel plus apirin). ${ }^{1,9,10}$

In conclusion, clopidogrel is a drug which is commonly used in the clinical practice, since many studies have demonstrated its efficacy in the atherosclerotic CV disease. Several studies showed that the administration of clopidogrel is associated with higher rates of GI bleeding. On the other hand, other studies suggested that the use of PPI following clopidogrel therapy, to minimize GI bleeding, may cause an increased rate of $\mathrm{CV}$ events, as both PPI and clopidogrel share the same metabolic pathway, involving CYP2C19 enzymes. Recent studies have attempted to investigate this issue. Though the results are conflicting, current expert recommendation stated that PPI should be considered to be given following clopidogrel therapy, particularly in patients with multiple risk factors for GI bleeding or receiving dual anti platelet therapy.

\section{REFERENCES}

1. Laine L, Hennekens C. Proton pump inhibitor and clopidogrel interaction: fact or fiction? Am J Gastroenterol. 2010;105:34-9.

2. Madanick RD. Proton pump inhibitor side effects and drug interactions: much ado about nothing? Cleveland Clinical Journal of Medicine. 2011;78:39-45.

3. Bhatt DL, Cryer BL, Contant CF, et al. Clopidogrel with or without omeprazole in coronary artery disease. N Engl J Med. 2010;363:1909-17.

4. Depta JP, Bhatt DL. Omeprazole and clopidogrel: should clinicians be worried? Cleveland Clinical Journal of Medicine. 2010;77:113-5.

5. Cryer BL. Reducing the risks of gastrointestinal bleeding with antiplatelet therapies. N Engl J Med. 2005;352:287-9.

6. Chan FK, Ching JY, Hung LC, et al. Clopidogrel versus aspirin and esomeprazole to prevent recurrent ulcer bleeding. New Engl J Med. 2005;352:238-44.

7. Vallurupalli NG, Goldhaber SZ. Gastrointestinal complications of dual antiplatelet therapy. Circulation. 2006;113:e655-8.

8. Ng FH, Wong SY, Lau YK, et al. Upper gastrointestinal bleeding during anti-platelet therapy. The Hong Kong Medical Diary. 2008;13:27-9.

9. Bhatt DL, Scheiman J, Abraham NS, et al. ACCF/ACG/ AHA 2008 expert consensus document on reducing the 
gastrointestinal risks of antiplatelet therapy and NSAID use: a report of the American college of cardiology foundation task force on clinical expert consensus documents. Circulation. 2008;118:1894-909.

10. Horn JR, Hansten PD. Clopidogrel-proton pump inhibitor interaction: an update. Pharmacy Times. 2010;02:47.

11. Abraham NS, Hlatky MA, Antman EL, et al. ACCF/ACG/ AHA 2010 expert consensus document on the concomitant use of proton pump inhibitors and thienopyridines: a focused update of the ACCF/ACG/AHA 2008 expert consensus document on reducing the gastrointestinal risks of antiplatelet therapy and NSAID use: a report of the American college of cardiology foundation task force on clinical expert consensus documents. Circulation. 2010;122:2619-33.

12. Zhang H, Ragueneau-Majlessi, Levy RH. Interaction between clopidogrel and proton pump inhibitors: hypothesis to explain multifactorial CYP2C19 inhibition. Drug Metabolism Letters. 2009;3:287-9.

13. Gilard M, Arnaud B, Cornily JC, et al. Influence of omeprazole on the antiplatelet action of clopidogrel associated with aspirin: the randomized, double-blind OCLA (Omeprazole CLopidogrel Aspirin) study. JACC. 2008;51:256-60.

14. Hulot JS, Collet JP, Silvain J, et al. Cardiovascular Risk in clopidogrel-treated patients according to cytochrome P450 $2 \mathrm{C} 19 * 2$ loss-of-function allele or proton pump inhibitor coadministration: a systematic meta-analysis. JACC. 2010;56:135-42.

15. Shuldiner AR, Connell JR, Bliden KP, et al. Association of cytochrome P450 2C19 genotype with the antiplatelet effect and clinical efficacy of clopidogrel therapy. JAMA. 2009;302:849-57.

16. Mega JL, Close SL, Wiviott SD, et al. Cytochrome P-450 polymorphisms and response to clopidogrel. N Engl J Med. 2009;360:354-62.

17. Kwok CS, Loke YK. Meta-analysis: the effects of proton pump inhibitors on cardiovascular events and mortality in patients receiving clopidogrel. Aliment Pharmacol Ther. 2010;31:810-23.

18. Lima JP, Brophy JM. Conflicting evidence: what's a clinician to do? Ann Intern Med. 2010;153:413-5. 